\title{
Delirium in the course of dependence upon gamma-butyrolactone (GBL) - a case report
}

\author{
Majaczenie w przebiegu uzależnienia \\ od gamma-butyrolaktonu (GBL) -opis przypadku \\ Łukasz Łobejko ${ }^{1}$ A,B,C,D,E,F, Piotr Machała ${ }^{1} \mathrm{~A}, \mathrm{~B}, \mathrm{C}, \mathrm{D}, \mathrm{E}, \mathrm{F}$, \\ Agata Makarewicz ${ }^{2} \mathrm{C}, \mathrm{D}, \mathrm{E}, \mathrm{F}$, Hanna Karakuła Juchnowicz ${ }^{2,3} \mathrm{C}, \mathrm{D}, \mathrm{E}, \mathrm{F}$ \\ ${ }^{1}$ Psychiatric Ward , Autonomous Public Healthcare in Leżajsk \\ ${ }^{2}$ I Department of Psychiatry, Psychotherapy and Early Intervention, Medical University of Lublin \\ ${ }^{3}$ Department of Clinical Neuropsychiatry, Medical University in Lublin
}

\begin{abstract}
Gamma-butyrolactone (GBL) is an organic chemical compound of the lactones group, undergoing biotransformation into gammahydroxybutyrate after the intake (GHB). Because of the easy access, low price and fast psychotropic effect, GBL is becoming increasingly popular substance having intoxicating effect. Taking of GBL causes dose-dependent euphoric, sedative, hypnotic effects. Its use can quickly lead to physical dependence with severe course of withdrawal syndromes. Withdrawal symptoms resemble those occurring in the course of addiction to alcohol or benzodiazepines. In some patients, delirium develops during substance withdrawal. There are described severe, life-threatening complications in the course of delirium in GBL-dependent patients. The management of withdrawal syndromes and delirium mainly involves administration of benzodiazepines. In this paper, we present a case of delirium in 24-year-old man addicted to GBL hospitalized in a psychiatric ward. Delirium in this patient went without complications and was successfully managed with diazepam and lorazepam.
\end{abstract}

Keywords: gamma-butyrolactone (GBL), gamma-hydroxybutyric acid (GHB), addiction, delirium

\section{Streszczenie}

Gamma-butyrolakton(GBL) jest organicznym związkiem chemicznym z grupy laktonów, ulegającym po spożyciu biotransformacji do kwasu gamma-hydroksymasłowego(GHB). Ze względu na łatwy dostęp, niską cenę i szybki efekt psychotropowy, GBL staje się coraz bardziej popularną substancją o działaniu odurzającym. Zażycie GBL wywołuje w zależności od dawki efekty euforyzujące, uspokajające, nasenne. Używanie go może szybko prowadzić do uzależnienia fizycznego z ciężko przebiegającymi zespołami abstynencyjnymi. Objawy zespołu abstynencyjnego przypominają te występujące w przebiegu uzależnienia od alkoholu czy benzodiazepin. U części pacjentów w trakcie odstawienia substancji rozwija się majaczenie. Opisywane są ciężkie, zagrażające życiu powikłania w przebiegu majaczeń u pacjentów uzależnionych od GBL. W leczeniu zespołów abstynencyjnych i majaczeń stosuje się głównie benzodiazepiny. W niniejszej pracy prezentujemy opis przypadku majaczenia u 24-letniego mężczyzny uzależnionego od GBL hospitalizowanego w oddziale psychiatrycznym. Majaczenie u tego chorego przebiegło bez powikłań i było skutecznie leczone diazepamem i lorazepamem.

Słowa kluczowe: gamma-butyrolakton(GBL), kwas gamma-hydroksymasłowy(GBH), uzależnienie, majaczenie.

Słowa kluczowe:

\section{Introduction}

Gamma-butyrolactone (GBL) is a solvent found, among others, in cleaners for car wheel rims, pesticides, cosmetics, medicines. After ingestion, it gets biotransformed to gamma-hydroxybutyric acid (GHB). Both substances belong to the so-called clubbing-culture drugs and are characterized by a dose-dependent euforic, sedative, hypnotic effects. They induce retroactive amnesia - they are used as so-called rape pills [1]. Other substances with similar chemical structure to the molecular structure of the gamma-hydroxybutyric acid, and causing the reaction similar to the effects of GHB include 1,4-butanediol (BD), gamma-valerolakton (GHV), gammahydroksywalerian (GVR) [2]. Acute intoxication with GBL and GBH causes, among others, disorders of consciousness, agitation, hallucinations, ataxia, dyskinesia, nystagmus, abnormal respiration, bradycardia, hypotension, vomiting [1]. It is believed that GBL has a more prolonged effect than GHB, and its intake in higher doses often leads to intoxication [2]. The use of both substances carries the risk of physical dependence of severe course of withdrawal syndromes. In Poland, GBL, unlike GHB, is not 
in the list of psychoactive drugs and psychotropic substances. Trading of GBL is not therefore subject to legal regulations - it is readily available, including online sales. The problem of usage and addiction to gammabutyrolactone is featured in Poland and many other countries [3]. GBL in almost pure form (99.9\%) is a component of e.g. cleaning liquid for car wheel rims and for removing printing inks and graffiti [1], and the easy availability and low price make it a popular intoxicating substance.

Gamma-butyrolactone (GBL) is an organic chemical compound of lactones group, oily liquid with strong odor and pungent taste, soluble in water and alcohol. GHB administered orally undergoes rapid resorption, metabolism and excretion in the urine. Finally, it is decomposed to water and carbon dioxide. The half-life of GHB is $20-53$ minutes. A single dose of GBL taken orally by drug users is usually 1-2 $\mathrm{ml}$ [1]. GBL is converted into gammahydroxybutyrate (GHB) under the influence of blood plasma lactamase. GHB is an endogenous substance acting as an inhibitory neurotransmitter in the central nervous system. It is produced from gamma-aminobutyric acid (GABA), to which it may be converted by itself. The mechanism of GHB action is due to its bond with two types of receptors: GHB-specific molecules (GHB receptors) and the GABA в receptors. GHB acts on the GABA в by GHB receptors. We speak of GHB- GABA в receptor complex. Endogenous GHB acts primarily by GHB-specific receptors, however, administered exogenously acts through the receptor complex. Stimulation of the receptor complex GHB-GABA в in the cortex of the frontal lobes is responsible for absence seizures as well as sedative effects, euphoria, hypnotic effects, an increase in the level of endogenous acetylcholine and serotonin. There is a hypothesis that low doses of GHB inhibit and high-doses stimulate the dopamine synthesis. In temporal cortex stimulation of the receptor complex by GHB causes hyperpolarization of hippocampal cortex and consequently amnesia. The action of GHB on receptor complex in the thalamus causes analgesic effects [1].

A similar mechanism associated with the effect on GABA receptors, serotoninergic and dopaminergic system makes the effect of consumption or abuse of GBL and GHB similar to the effect of consumption or abuse of alcohol and benzodiazepines. The impact of repeated doses on the reward- punishment system is responsible for the development of addiction. Physical dependence may develop after 3 months of regular intake of repeated doses [4].

Regular use of GBL and GHB leads to a tolerance that is associated with an increase in the synthesis of the enzymes responsible for the GHB metabolism. Symptoms of withdrawal syndrome are similar to those occurring in the course of addiction to alcohol or benzodiazepines. Most frequently anxiety, tremors, insomnia, hallucinations, tachycardia, increased blood pressure are observed [1]. In the withdrawal syndromes associated with the use of GBL and GBH qualitative disorders of consciousness may develop.

\section{Aim}

The aim of the study was to describe the case of delirium in the GBL-dependent patient, hospitalized in the Psychiatric Ward in Leżajsk.

\section{Case study}

Twenty-four-year-old man was brought to the hospital by worried by his behavior family. The patient was in a significantly increased psychomotor drive and severe anxiety resulting from a psychotic experience, in full autopsychical orientation, with only a rough orientation in time, place and situation. He confirmed experiencing intense auditory hallucinations. On the way to the hospital, he tried to jump out of the car. Both the patient and his family admitted that he was abusing psychoactive substances. In medical history, it was found that the patient had been taking orally gamma-butyrolactone (GBL), every day for at least six months. During this period, he presented to the psychiatrist 2 times because of worsening of insomnia and anxiety. He was taking drugs prescribed by a psychiatrist (clorazepate, alprazolam, quetiapine, hydroxyzine), but was not able to stop the drug addiction. In the last weeks before hospitalization, he was taking 20 to $40 \mathrm{~mL}$ of GBL per day. Due to the presence of psychotic symptoms, it was decided to refer the patient to the Psychiatric Ward. Within 6 hours of admission to the ward , the patient developed fully symptomatic consciousness disorders of delirium type. He presented total allopsychical confusion. Auditory hallucinations intensified, he experienced visual hallucinations, too. He spoke of persecutory delusions, a sense of danger was growing in him, and he tried to flee from the imaginary persecutors, trying to break the glass in the window, hitting it with a chair. Because he posed a threat for himself and other patients, he required a forced immobilization and forced administration of drugs in injectable form. On admission to the hospital, routine laboratory tests of blood and urine of the patient were performed. In the results, a slight increase in the level of total bilirubin $(1.04 \mathrm{mg} / \mathrm{dL}$ with laboratory standard below $1.0 \mathrm{mg} / \mathrm{dl}$ ) was found. Drug test showed the presence of benzodiazepines in urine. The tests results within the next days confirmed slight increase in blood urea (54 mg / dl with a laboratory standard $15-45 \mathrm{mg} / \mathrm{dL}$ ) and reduced levels of potassium ( $3.77 \mathrm{mmol} / \mathrm{l}$ with laboratory standard 4.0 - $5.5 \mathrm{mmol} / \mathrm{l}$ ). Other test results (blood count, serum creatinine, liver transaminases, thyrotropin, urinalysis) were normal. 
Patient's general condition was quite good. Arterial blood pressure fluctuated around $120 / 75 \mathrm{mmHg}$, the heart rate of 100 to 110 beats per minute. Body temperature was raised - the highest measured value was $38.3^{\circ} \mathrm{C}$ in the second day of delirium. Tremor of the body and sweating enhancement were not too severe, unlike in delirium caused by alcohol addiction.

The patient was managed with diazepam - intravenously in physiological saline solution at a dose of $40 \mathrm{mg}$ per day. Also other drip infusions were administered - a multi electrolyte-fluid and potassium chloride in physiological saline solution. Delirium subsided after 48 hours. After this time, the subject was properly oriented in time, place and situation, did not utter delusional contents, did not hallucinate. His psychomotor drive leveled off, anxiety subsided. Then diazepam was replaced with lorazepam. Lorazepam was administered orally, with a maximum daily dose of $7.5 \mathrm{mg}$. Lorazepam dose was gradually reduced until complete withdrawal on day 10 of hospitalization. After consciousness disorders subsided, a CT scan of the head was performed (without contrast and after intravenous administration of contrast). CT scan showed no pathology in terms of the central nervous system. After 15 days of hospitalization, the patient was discharged home in good general condition and stable mental state with the recommendation to take addiction treatment and regular psychiatric care.

\section{Discussion}

Gamma-butyrolactone (GBL) is easily accessible and therefore more frequently used substance with psychoactive effects. It affects, among others, the GABAergic system [1]. Physical dependence may develop after 3 months of its regular intake [4]. Withdrawal symptoms in addicts are similar to those observed in the course of addiction to alcohol or benzodiazepines [1]. Withdrawal syndromes can be effectively managed using diazepam on an outpatient basis [7]. In some patients, in the course of the withdrawal syndrome delirium develops. Delirious patients and patients severely intoxicated with GBL require hospital treatment. The literature describes the occurrence of serious, life-threatening complications of delirium caused by GBL addiction. The authors reported among other things, respiratory failure and acute renal failure $[4,10,11]$. In the management of withdrawal syndromes and delirium in GBLaddicted patients using of benzodiazepines is recommended $[1,2,4,5,6,7,9]$. In order to control a significant agitation, administration of haloperidol may be helpful [4,5]. Due to the possibility of life-threatening complications, it is necessary to monitor carefully the patient's general condition.
There are reports of successful treatment of GBLwithdrawal syndromes with benzodiazepines. Zepf et al. [5] presented a case of GBL-addicted 16-year-old boy in delirium. The patient was treated with diazepam at a dose of $30 \mathrm{mg}$ per day, and then - in the absence of sufficient improvement - with haloperidol. Fink [6] in a letter to the editor deems such management incorrect. He recommends the use of higher daily doses of benzodiazepines equivalent to $20 \mathrm{mg}$ lorazepam. Bell and Collins [7] describe outpatient detoxification of 17 patients addicted to GBL. They were treated with diazepam in the maximum daily dose to $110 \mathrm{mg}$ on the first day of treatment. In 16 patients, outpatient detoxification proceeded without complications. In the case of one patient delirium developed, which required hospitalization. Lingford-Hughes et al. [8] report the treatment of withdrawal syndromes in the course of addiction to GHB and GBL. They report the benefits of the use of baclofen. Administration of baclofen at a dose of $30 \mathrm{mg}$ per day reduces the severity of withdrawal symptoms and the number of complications during treatment. Ghio et al. [9] basing on the review of the reports indicate the high doses of benzodiazepines used to detoxify GBL-addicted patients. They also propose considering the treatment of withdrawal syndromes with barbiturates - as a method of first choice. Other authors warn about the serious complications in the course of delirium caused by GBL-addiction. Chwaluk and Rejmak [4] describe a case of hospitalization of 23-year-old GBLaddicted man, for a few hours being in a coma and requiring assisted respiration initially. Considerable psychomotor agitation caused by consciousness disturbances continued in this patient for more than 3 days and it was controlled with intravenous injections of diazepam (70 mg once) and haloperidol (25 mg once). Voluntary movement of myoclonus character accompanied agitation. Supady et al. [10] report the case of respiratory failure complicated by delirium, myoclonus syndrome and acute renal failure in a 24-year-old man addicted to GBL. Severe condition of the patient required intubation and dialysis. Bhattacharya et al. have also reported the delirium in GBL-addiction complicated by acute renal failure [11].

\section{Conclusions}

In everyday work of the clinician, particular attention should be paid to the possible causes of psychoses, especially disorders associated with disturbances of consciousness. Today psychoactive substances constantly evolve, and the "black market" still provides new opportunities for intoxication. Knowledge of the mechanism of action of these substances determines the effective aid in life-threatening conditions of the patient after taking the substances. 


\section{Wstęp}

Gamma- butyrolakton(GBL) jest rozpuszczalnikiem wchodzącym w skład m.in. środków do czyszczenia felg samochodowych, środków ochrony roślin, kosmetyków, leków.Po spożyciu ulega biotransformacji do kwasu gamma-hydroksymasłowego(GHB). Obie substancje należą do tzw. narkotyków klubowych i odznaczają się zależnym do dawki działaniem euforyzującym, uspokajającym, nasennym. Wywołują niepamięć wsteczną- są stosowane jako tzw. pigułki gwałtu [1]. Inne substancje o strukturze chemicznej podobnej do budowy cząsteczkowej kwasu gamma-hydroksymasłowego i wywołujące działanie zbliżone do efektów GHB to: 1,4-butanediol(BD), gammavalerolakton(GHV), gamma-hydroksywalerian(GVR) [2]. Ostre zatrucie GBL i GBH powoduje m.in. zaburzenia świadomości, pobudzenie, halucynacje, ataksję, dyskinezy, oczopląs, zaburzenia oddychania, bradykardię, spadek ciśnienia tętniczego, wymioty [1]. Uważa się, że GBL działa dłużejniż GHB, a zażycie go w większej ilości częściej prowadzi do zatrucia [2]. Używanie obu substancji niesie ryzyko rozwoju fizycznego uzależnienia z ciężko przebiegającymi zespołami abstynencyjnymi. W Polsce GBL, przeciwnie niż GHB, nie znajduje się w wykazie środków odurzających i substancji psychotropowych. Obrót GBL nie podlega zatem regulacjom prawnym-jest on łatwo dostępny, również w sprzedaży internetowej. Problem używania i uzależnienia od gamma-butyrolaktonu jest opisywany w Polsce i wielu innych państwach [3].GBL w niemal czystej postaci(99,9\%) jest składnikiem płynu do czyszczenia felg samochodowych oraz do usuwania farb drukarskich i graffiti [1], a łatwa dostępność i niska cena czynią go popularną substancją odurzającą.

Gamma-butyrolakton(GBL) to organiczny związek chemiczny z grupy laktonów, oleista ciecz o intensywnym zapachu i ostrym smaku, dobrze rozpuszczalna w wodzie i alkoholu. GHB przyjęty doustnie ulega szybkiej resorpcji, metabolizmowi i wydalaniu z moczem. Ostatecznie rozkładany jest do wody i dwutlenku węgla. Okres półtrwania GHB wynosi 20-53 minuty. Jednorazowa dawka GBL zażywana doustnie przez osoby odurzające się to najczęściej 1-2 ml [1].GBL przekształca się do gammahydroksymaślanu (GHB) pod wpływem laktamazy osocza krwi.GHB jest endogenną substancją pełniącą funkcję neurotransmitera hamującego $\mathrm{w}$ ośrodkowym układzie nerwowym. Powstaje on $\mathrm{z}$ kwasu gammaaminomasłowego (GABA), w który sam może się przekształcać. Mechanizm działania GHB wynika z jego wiązania się z dwoma rodzajami receptorów: specyficznymi dla cząsteczek GHB(receptory dla GHB) i receptorami GABA GHB działa na receptor $\mathrm{GABA}_{\mathrm{B}}$ za pośrednictwem receptorów GHB. Mówimy o kompleksie receptorowym GHB-

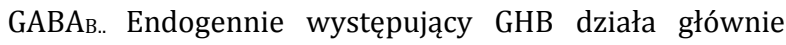
poprzez receptory specyficzne dla GHB, natomiast poda- wany egzogennie działa poprzez kompleks receptorowy. Stymulacja kompleksu receptorowego GHB-GABAв w korze płatów czołowych odpowiada za napady nieświadomości a także za efekty uspokajające, euforyzujące, nasenne, wzrost poziomu endogennej acetylocholiny i serotoniny. Istnieje hipoteza, że małe dawki GHB hamują a wysokie dawki pobudzają syntezę dopaminy. W korze płatów skroniowych stymulacja kompleksu receptorowego przez GHB powoduje hiperpolaryzację kory hipokampa i w efekcie amnezję. Działanie GHB na kompleks receptorowy we wzgórzu powoduje efekty znieczulające [1].

Podobny mechanizm działania, związany z wpływem na receptory GABA, układ dopaminergiczny i serotoninergiczny sprawia, że efekt spożycia i nadużywania GBL i GHB jest podobny do efektu spożycia i nadużywania alkoholu i benzodiazepin. Wpływ powtarzalnych dawek na układ nagrody i kary odpowiedzialny jest za rozwój uzależnienia. Uzależnienie fizyczne może rozwinąć się już po 3 miesiącach regularnego przyjmowania powtarzanych dawek [4].

Regularne zażywanie GBL i GHB prowadzi do wytworzenia tolerancji, która związana jest ze wzrostem syntezy enzymów odpowiedzialnych za metabolizm GHB. Objawy zespołu abstynencyjnego podobne są do tych występujących w przebiegu uzależnienia od alkoholu czy benzodiazepin. Najczęściej obserwuje się lęk, drżenia, bezsenność, omamy, tachykardię, wzrost ciśnienia tętniczego [1]. W zespołach abstynencyjnych związanych $\mathrm{z}$ używaniem GBL czy GBH mogą rozwinąć się jakościowe zaburzenia świadomości.

\section{Cel pracy}

Celem pracy było przedstawienie opisu przypadku majaczenia u pacjenta uzależnionego od GBL, hospitalizowanego w Oddziale Psychiatrycznym w Leżajsku.

\section{Opis przypadku}

24-letni mężczyzna został przywieziony do szpitala przez zaniepokojoną jego zachowaniem rodzinę. Pacjent był w znacznie wzmożonym napędzie psychoruchowym i nasilonym lęku wynikającym z przeżyć psychotycznych, prawidłowo zorientowany autopsychicznie, $z$ jedynie przybliżoną orientacją $\mathrm{w}$ czasie, miejscu i sytuacji. Potwierdzał przeżywanie intensywnych halucynacji słuchowych. W trakcie jazdy do szpitala próbował wyskoczyć z samochodu. Zarówno pacjent, jak i jego rodzina przyznali, że nadużywa on substancji psychoaktywnych. W trakcie wywiadu ustalono, że pacjent przyjmował doustnie gamma-butyrolakton(GBL), codziennie, od co najmniej 6 miesięcy. W tym czasie 2 razy zgłosił się do psychiatry z powodu nasilającej się bezsenności i lęku. Przyjmował przepisane przez psychiatrę leki(klorazepat,alprazolam, kwe- 
tiapinę, hydroksyzynę), lecz nie był w stanie przerwać ciągu narkotykowego. W ostatnich tygodniach przed hospitalizacją zażywał od 20 do $40 \mathrm{ml}$ GBL na dobę. Z uwagi na obecność objawów psychotycznych zdecydowano o przyjęciu chorego do Oddziału Psychiatrii. W ciągu 6 godzin od przyjęcia do szpitala u chorego rozwinęły się pełnoobjawowe zaburzenia świadomości typu majaczenia. Był zupełnie zdezorientowany allopsychicznie. Nasiliły się omamy słuchowe, doznawał też omamów wzrokowych. Wypowiadał treści o charakterze urojeń prześladowczych, narastało u niego poczucie zagrożenia, próbował uciekać przed urojonymi prześladowcami. Usiłował zbić szybę w oknie uderzając w nią krzesłem. Z powodu stwarzanego dla siebie i innych chorych zagrożenia wymagał przytrzymania, unieruchomienia i przymusowego podania leków w formie iniekcyjnej. W dniu przyjęcia do szpitala wykonano rutynowe badania laboratoryjne krwi i moczu pacjenta. W uzyskanych wynikach stwierdzono niewielkie podwyższenie poziomu bilirubiny całkowitej $(1,04 \mathrm{mg} / \mathrm{dl}$ przy normie laboratorium poniżej $1,0 \mathrm{mg} / \mathrm{dl}$ ).Test narkotykowy wykazał obecność benzodiazepin $\mathrm{w}$ moczu. $\mathrm{W}$ badaniach wykonanych $\mathrm{w}$ trakcie kolejnych dni obserwowano wzrost poziomu mocznika (54 mg/dl przy normie laboratorium $15-45 \mathrm{mg} / \mathrm{dl}$ ) i obniżenie poziomu potasu $(3,77 \mathrm{mmol} / \mathrm{l}$ przy normie laboratorium 4,0-5,5 mmol/l). Pozostałe wyniki badań (morfologia krwi, poziom kreatyniny, transaminaz wątrobowych, tyreotropiny, analiza moczu) nie odbiegały od normy.Stan ogólny chorego był dość dobry. Ciśnienie tętnicze krwi oscylowało wokół 120/75 mmHg, czynność serca 100 do 110 uderzeń na minutę. Temperatura ciała była podwyższona-najwyższa zmierzona wartość to $38,3{ }^{\circ} \mathrm{C}$ w drugiej dobie majaczenia. Drżenie ciała i wzmożenie potliwości były niezbyt nasilone, odmiennie niż w majaczeniach wywołanych uzależnieniem od alkoholu.

W leczeniu chorego zastosowano diazepam - podawany dożylnie w roztworze soli fizjologicznej, w dawce do $40 \mathrm{mg}$ na dobę. Podawano też inne wlewy kroplowe-płyn wieloelektrolitowy i chlorek potasu $\mathrm{w}$ roztworze soli fizjologicznej. Majaczenie ustąpiło po 48 godzinach. Po upływie tego czasu pacjent był już prawidłowo zorientowany w miejscu, czasie i sytuacji, nie wypowiadał treści urojeniowych, nie halucynował. Jego napęd psychoruchowy wyrównał się, lęk ustąpił. Wówczas diazepam zastąpiono lorazepamem. Lorazepam przyjmowany był przez pacjenta w postaci doustnej, w maksymalnej dawce dobowej 7.5mg. Dawkę lorazepamu stopniowo zmniejszano aż do zupełnego odstawienia w 10 dobie hospitalizacji. Po ustąpieniu zaburzeń świadomości wykonano tomografię komputerową głowy(bez podania kontrastu i po dożylnym podaniu kontrastu). Badanie tomograficzne nie wykazało patologii w zakresie ośrodkowego układu nerwowego. Po 15 dniach hospitalizacji pacjent został wypisany do domu w dobrym stanie ogólnym i stabilnym stanie psychicznym z zaleceniem podjęcia terapii odwykowej i systematycznej opieki psychiatrycznej.

\section{Dyskusja}

Gamma-butyrolakton (GBL) jest łatwo dostępną i przez to coraz częściej stosowaną substancją o działaniu psychoaktywnym. Oddziaływuje ona m.in. na układ gabaergiczny [1]. Uzależnienie fizyczne może rozwinąć się już po 3 miesiącach jej regularnego przyjmowania [4]. Objawy zespołu abstynencyjnego u osób uzależnionych podobne są do tych obserwowanych w przebiegu uzależnienia od alkoholu czy benzodiazepin [1]. Zespoły abstynencyjne mogą być skutecznie leczone ambulatoryjnie za pomocą diazepamu [7]. U części pacjentów w czasie trwania zespołu abstynencyjnego rozwija się majaczenie. Chorzy majaczący, jak i chorzy w stanie ciężkich zatruć GBL wymagają leczenia szpitalnego. W literaturze opisano występowanie poważnych, zagrażających życiu powikłań w przebiegu majaczeń spowodowanych uzależnieniem od GBL. Autorzy donosili m.in. o niewydolności oddechowej i ostrej niewydolności nerek $[4,10,11]$. W leczeniu zespołów abstynencyjnych i majaczenia u pacjentów uzależnionych od GBL zalecane jest stosowanie benzodiazepin $[1,2,4,5,6,7,9]$. W celu opanowania znacznego pobudzenia pomocne może być podawanie haloperidolu [4,5]. Z uwagi na możliwość zagrażających życiu powikłań konieczne jest uważne monitorowanie stanu ogólnego chorego.

W literaturze przedmiotu istnieją doniesienia o skutecznym leczeniu benzodiazepinami wywołanych przez GBL zespołów abstynencyjnych. Zepf i wsp. [5] prezentują opis przypadku 16-letniego chłopca majaczącego w wyniku uzależnienia od GBL. Pacjent leczony był diazepamem w dawce do $30 \mathrm{mg}$ na dobę, a następnie - wobec braku wystarczającej poprawy haloperidolem.Fink [6] w liście do wydawcy uważa takie postępowanie za błędne. Rekomenduje on stosowanie wyższych dobowych dawek benzodiazepin- do ekwiwalentu $20 \mathrm{mg}$ lorazepamu. Bell i Collins [7] opisują ambulatoryjną detoksykację 17 pacjentów uzależnionych od GBL. Podawano im diazepam w maksymalnej dawce dobowej do $110 \mathrm{mg} \mathrm{w}$ pierwszej dobie leczenia. U 16 pacjentów detoksykacja ambulatoryjna przebiegła bez powikłań. W przypadku 1 pacjenta rozwinęło się majaczenie i wymagał on hospitalizacji. Lingford-Hughes i wsp. [8] opisują leczenie zespołów abstynencyjnych w przebiegu uzależnienia od GHB i GBL. Donoszą o korzyściach płynących ze stosowania baklofenu. Podawanie baklofenu w dawce $30 \mathrm{mg}$ na dobę zmniejsza nasilenie objawów abstynencyjnych i ilość powikłań w trakcie leczenia.Ghio i wsp. [9] w relacji z przeglądu doniesień informują o wysokich dawkach benzodiazepin stosowanych w detoksykacji pacjentów uzależnionych od GBL. Proponują też rozważenie leczenia zespołów absty- 
nencyjnych barbituranami - jako metody pierwszego wyboru. Inni autorzy ostrzegają o groźnych powikłaniach w przebiegu majaczeń spowodowanych uzależnieniem od GBL.Chwaluk i Rejmak [4] opisują przypadek hospitalizacji 23-letniego mężczyzny uzależnionego od GBL, przez kilka godzin będącego w śpiączce i wymagającego początkowo oddechu wspomaganego. Znaczne pobudzenie psychoruchowe spowodowane zaburzeniami świadomości trwało u tego chorego ponad 3 doby i było opanowywane za pomocą iniekcji dożylnych diazepamu(do $70 \mathrm{mg}$ jednorazowo) i haloperidolu(do $25 \mathrm{mg}$ jednorazowo). Pobudzeniu towarzyszyły ruchy dowolne o charakterze mioklonii. Supady i wsp. [10] relacjonują przypadek majaczenia powikłanego niewydolnością oddechową, miokloniami i ostrą niewydolnością nerek u 24-letniego mężczyzny uzależnionego od GBL. Ciężki stan ogólny tego chorego wymagał zastosowania intubacji i dializ. 0 majaczeniu w uzależnieniu od GBL powikłanym ostrą niewydolnością nerek donoszą również Bhattacharya i wsp. [11].

\section{Wnioski}

W codziennej pracy klinicysty należy zwracać szczególną uwagę na możliwe przyczyny psychoz, szczególnie przebiegających z zaburzeniami świadomości. Współcześnie substancje psychoaktywne stale ewaluują, a „czarny rynek” wciąż dostarcza nowych możliwości odurzania się. Znajomość mechanizmu działania tych substancji warunkuje skuteczną pomoc $\mathrm{w}$ warunkach zagrożenia życia pacjenta po zażyciu substancji.

\section{References:}

1. Krajewska A., Kwiecień-Obara E., Szponar J., Majewska M., Kołodziej M. Kwas gamma-hydroksymasłowy(GHB) i jego lakton(GBL) jako substancje psychoaktywne. Przegląd Lekarski, 2012; 69/8: 544-447.
2. Poprawska O. Gamma-hydroksymaślan(GHB)-„Narkotyk gwałtu,,.Psychiatria i Psychologia Kliniczna, 2005; Vol 5 No 1: 144-150.

3. Gamma - butyrolactone(GBL). Critical Review Report. Agenda item 4.3 Expert Committee on Drug Dependence. Thirthy-sixth Meeting, Geneva 16-20 June 2014. WHO.

4. Chwaluk P., Rejmak G. Ostre zatrucie gamma-butyrolaktonem z zespołem abstynencyjnym. Przegląd Lekarski, 2011; 68/8: 537-538.

5. Zepf F.D.,Holtmann M., Duketis E., Maier J., Radeloff D., Wagner A., Poustka F., Wockel L. A 16 -year old boy with severe gammabutyrolactone(GBL) withdrawal delirium. Pharmacopsychiatry. 2009 Sep; 42(5): 202-203.

6. Fink M.Letter to the Editor. Pharmacopsychiatry 2010 Jun; 43(4): 157.

7. Bell J., Collins R. Gamma-butyrolactone(GBL) dependence and withdrawal. Addiction. 2011 Feb; 106(2): 442-447.

8. Lingford-Hughes A., Patel Y., Bowden-Jones O., Crawford MJ., Dargan PI., Gordon F., Parrott S., Weaver T., Wood DM. Improving GHB withdrawal with baclofen: study protocol for a feasibility study for a randomized controlled trial. Trials. 2016 Sep 27;17(1): 472.

9. Ghio L., Cervetti A., Respino M., Belvederi Murri M., Amore M. Management and treatment of gamma butyrolactone withdrawal syndrome: a case report and review. J. Psychiatr. Pract. 2014 Jul;20(4): 294-300.

10. Supady A., Schwab T., Busch HJ. "Liquid ecstasy": gammabutyrolactone withdrawal delirium with rhabdomyolysis and dialysis dependent renal failure. Dtsch. Med. Wochenschr, 2009 Apr; 134(18): 935-937.

11. Bhattacharya IS., Watson F., Bruce M. A case of gammabutyrplactone associated with severe withdrawal delirium and acute renal failure. Eur. Addict. Res. 2011; 17(4): 169-171.

\section{Correspondence address}

Łukasz Łobejko

Oddział Psychiatryczny w SP ZOZ w Leżajsku

37-300 Leżajsk, ul. Leśna 22, Tel. 172404930

Otrzymano: 10.11.2016

Zrecenzowano: 15.12.2016

Przyjęto do druku: 19.12.2016 